Jette Pedersen

\title{
Koncernspecifik brancheordbog med særligt henblik på teknisk engelsk: Prækonceptionelle overvejelser og koncept
}

I det følgende gives en præsentation af nogle centrale aspekter af ovennævnte Ph.D.-afhandling, som jeg forsvarede på Handelshøjskolen i Århus i juni 1995. Der var for det 2 1/2-årige projekt, som afhandlingen var en del af, tale om en bunden opgave, idet temaet var fastlagt på forhånd: Udarbejdelse af et ordbogskoncept, der tager højde for en branches oversættelsesbehov. Ud over selve afhandlingen skulle der desuden som en del af projektet udarbejdes en virksomhedsspecifik dansk-engelsk/engelsk-dansk pumpeteknologisk ordbog.

\section{Baggrunden for projektet}

Når det drejer sig om forhåndenværende bilingvale danske ordbogsudgivelser inden for det tekniske fagområde, har flerfagsordbøger hidtil stort set været enerådende. Dette gælder således de to seneste udgivelser for sprogparret dansk-engelsk: L\&H Teknisk Ordbog. Dansk-engelsk/engelsk-dansk og Dansk-engelsk/engelsk-dansk teknisk ordbog fra Clausen, som indeholder henholdsvis 90.000 og 30.000 lemmata hver vej. I betragtning af at disse er fordelt på ikke mindre end 161 henholdsvis 129 emneområder, vil sådanne bredt anlagte flerfagsordbøger næppe kunne give fyldestgørende informationsdybde og -bredde for samtlige de involverede områder. Dette gælder i særlig grad, når det ved optællinger i L\&H kan konstateres, at knap halvdelen af samtlige emneangivelser under bogstaverne $\mathrm{D}$ og J begrænser sig til blot fire af de forudsete 161 emneområder. Dette kan bl.a. hænge sammen med utilstrækkelige overvejelser vedr. den empiriske basis, som for begge udgivelsers vedkommende forekommer tilfældig og usystematisk. Således er L\&H efter det oplyste blevet til på baggrund af foreliggende tekstmateriale i et oversættelsesbureau, mens det i ordbogen fra Clausen blot anføres, at det for ordbogen tilgrundliggende "indsamlede materiale findes i en database". Efter opslag i denne ordbogstype vil oversætteren/tekstproducenten derfor typisk befinde sig i den situation, at der resterer et uforholdsmæssigt stort antal termer, som det overhovedet ikke har været muligt at slå op, eller hvor de opgivne ækvivalenters anvendelighed i en konkret sammenhæng må betegnes som usikker, jvf. nedenstående eksempel fra $L \& H$ :

fedtudskiller fat collector, grease removal tank, grease remover, grease separator, grease skimming tank, grease trap; [spild.] fast collector, fat separator, fat trap 
Specielt når det drejer sig om den ikke-fagkompetente oversætter, kan denne usikkerhed have sit udspring i forståelsesproblemer. Da traditionelle bi- og polylingvale fagordbøger typisk kun intenderer at yde begrænset hjælp, om overhovedet, til løsning af forståelsesbetingede problemer, vil oversætteren være henvist til at søge efter og gennemlæse relevante paralleltekster i læreeller håndbøger, encyklopædier, leksika, standarder, virksomhedsinternt materiale m.v. For at afhjælpe dette problem samt sikre et vist mål af ensartethed i den fremmedsproglige kommunikation har im- og ekportvirksomheder i stigende grad set sig henvist til at etablere deres egne systemer, typisk i form af upublicerede virksomhedsinterne bi- eller polylingvale termlister, jvf. følgende uddrag fra Grundfos dansk - engelsk - tysk - fransk pumpeteknologisk ordliste:

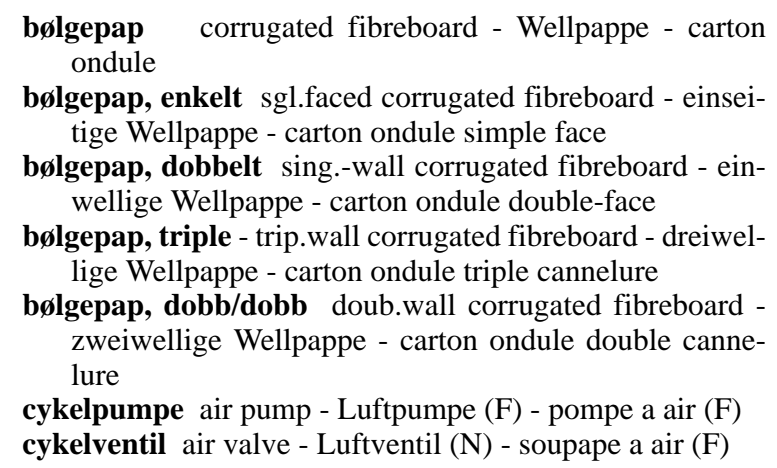

Ikke mindst i betragtning af at den pumpeteknologiske ordliste kun omfatter 800 lemmata, kan det undre, at en bestemt emballeringsform skal optage fem lemmapositioner. Der må således sættes spørgsmålstegn ved den tilgrundliggende empiriske basis og de i forbindelse hermed anlagte selektionskriterier, jvf. f.eks. også cykelventil, som overhovedet ikke forekommer i en i forbindelse med nærværende projekt oprettet virksomhedsspecifik dansk tekstsamling på omkring en halv million løbende tekstord. I det hele taget må værdien af termlister som entydigt sprogligt hjælpeværktøj anses for tvivlsom netop på grund af disses rene listekarakter, kun med lemmata og fremmedsproglige ækvivalenter. Hvor det, som i det konkrete tilfælde, drejer sig om en koncern med et internationalt koncernsprog, kommer hertil, at termlister ikke kan medvirke til at sikre ensartethed i sprogbrugen for koncernen som helhed.

\section{Prækonceptionelle overvejelser}

Netop det forhold at der er valgt et koncernsprog må få en række konsekvenser ikke alene for grundkonceptet, men også for konciperingen af de enkelte informationskategorier. Der er i det aktuelle tilfælde tale om en dansk-baseret 
international koncern med koncernsproget engelsk, som således hverken er identisk med hjemlandets sprog eller de sprog, som tales i de øvrige selskaber inden for koncernen, hvor engelsk ikke er modersmål. Udarbejdelse af den forudsete bilingvale dansk-engelske/engelsk-danske ordbog ville derfor være ensbetydende med en forhåndsindskrænkning af ordbogens potentielle brugere til koncernens hjemland med hovedvægten på funktionen oversættelse fra hjemlandets sprog til koncernsproget - og den modsatte vej ... Der savnes specielt hensyntagen til brugerne i de udenlandske selskaber, der foruden at recipere tekster på koncernsproget som et mål i sig selv også kan komme ud for på basis heraf at skulle producere tekster på henholdsvis oversætte tekster til de pågældende nationale sprog. Som leksikografisk løsning foreslås en selvstændig monolingval ordbog på koncernsproget. Under forudsætning af, at de nødvendige informationskategorier indarbejdes, indebærer et sådant grundkoncept en direkte hensyntagen til brugsfunktionerne produktion og reception af tekster på koncernsproget for alle involverede modersmålsbrugere. I og med at ordbogen er universelt anvendelig, kan den desuden medvirke til at sikre standardisering af sprogbrugen inden for koncernen som helhed. Samtidig åbner konceptet mulighed for en mere direkte hensyntagen til brugsfunktionen oversættelse, idet ordbogen efterfølgende vil kunne udbygges med en bilingval dimension $\mathrm{i}$ form af en supplerende dansk-engelsk lemmaliste foruden det antal bilingvale, monodirektionale lemmalister fra koncernsproget til de $\varnothing v$ vrige nationale sprog, der måtte være behov for - derfor betegnelsen basisordbog.

Også ved sin indgang til fagområdet lægger projektet op til fagleksikografisk nytænkning. Der er her tale om, hvad jeg har valgt at benævne en brancheordbog, forstået som en ordbog, der har et bestemt fags produkter som sit genstandsområde. Ud over et bestemt prioriteret del- eller enkeltfag vil en brancheordbog typisk også indeholde informationer vedrørende associerede eller mere perifere fagområder. Herved adskiller den sig fra allerede eksisterende, sammenlignelige fagordbogstyper, således f.eks. koncernordbøger, der intenderer at dække et bredt udsnit af alle de fagtermer og -udtryk, der forekommer i en given koncerns tekstproduktion, og del- og enkeltfagsordbøger, der er karakteriseret ved ikke at inddrage emneområder, der ligger uden for et bestemt del- eller enkeltfag.

Drejer det sig som her om en virksomhedsspecifik brancheordbog, følger det, at den pågældende virksomheds tekstproduktion må indgå som en nødvendig del af ordbogens empiriske basis. I modsætning til hvad der ville være tilfældet, hvis der havde været tale om en koncernordbog, er der for en brancheordbog behov for at begrænse tekstgrundlaget til indholdsmæssig og terminologisk præcis teknisk information om produktprogrammet. Hermed fravælges dels direktive tekster, idet disse er karakteriseret ved en bevidst nedprioritering af det faglige indhold, dels terminologisk tentative tekster, typisk tekster 
som er produceret i en virksomheds forsknings- eller udviklingsafdeling. Konciperes en fagordbog som her med en omfattende mikrostruktur, hvilket var det monolingvale grundkoncepts forudsætning, er det dog ikke tilstrækkeligt med det tekstfundament, virksomheden kan levere, idet dette for en stor del vil bestå af relætekster. For at sikre pålideligheden af specielt de grammatiske og kollokationelle oplysninger er det påkrævet med et autentisk, virksomhedseksternt tekstkorpus. Med henblik på sammensætningen heraf må der etableres et overblik over tekstuniverset, ligesom der med henblik på selektion må opstilles nødvendige tematiske og teksttypologiske kriterier, på samme måde som også kommunikationsretninger inddrages i overvejelserne. Med henblik på etablering af et systematisk overblik over en brancheordbogs prioriterede delfagsområde foreslås udarbejdet en såkaldt ekstern fagsystematik. Denne har dels til formål at afgrænse det pågældende prioriterede delfagsområde i forhold til tilgrænsende områder og dermed sikre udelukkelse af delfagseksterne tekster, dels skal den sikre, at det pågældende fagområde dækkes og afdækkes i hele sin udstrækning. For at sikre, at den empiriske basis er til stede for den leksikografiske behandling af de aspekter, der er omfattet af det pågældende fagområde, udarbejdes desuden en såkaldt aspektfortegnelse.

De uheldige konsekvenser af manglende lemmatiseringsovervejelser påvises og dermed behovet for en teoretisk afklaring af de for lemmaselektion tilgrundliggende principper. Det må således sikres, at samtlige det prioriterede fagområdes termer lemmatiseres i ordbogen. Med henblik på maksimerende selektion af fagtermer foreslås udarbejdelse af systematiserede oversigter over det pågældende områdes fagterminologi, i form af hvad jeg har valgt at benævne termsystematikker. Med udgangspunkt heri foreslås følgende selektionskriterium: 1) Fagtermer i henhold til en systematisk ordning af det prioriterede delfagsområde. Der tages altså udelukkende udgangspunkt i faget, nærmere betegnet i viden om faget. Mens metoden således sikrer en terminologisk dækkende ordbog, er den ingen garanti for, at de selekterede termer rent faktisk optræder i de tekster, der produceres inden for faget. Omvendt er der i forbindelse med de to følgende tekstbaserede, minimerende fremgangsmåder ingen garanti for, at der overhovedet vil blive selekteret deciderede termer fra de pågældende fagområder. Dette er i overensstemmelse med intentionerne med en brancheordbog. Branche- og koncernordbøger adskiller sig som nævnt fra del- og enkeltfagsordbøger ved også at intendere at medtage emneområder, der ligger uden for det prioriterede fagområde. Der er for det aktuelle projekt identificeret to såkaldt associerede fagområder, nemlig elmotorer og elektronik, idet den pågældende virksomhed selv producerer de elmotorer og elektroniske styringer, der indgår i pumpeprogrammet. For associerede fagområder foreslås selekteret: 2) Fagudtryk, der er omfattet af produktprogrammet og som indgår i virksomhedens tekstproduktion. Yderligere vil der i brancheordbogssam- 
menhæng være behov for at selektere fagudtryk fra en række mere perifere emneområder, der ikke, således som det var tilfældet med associerede fagområder, har direkte relation til produktprogrammet, men f.eks. alene til de for fremstillingen heraf tilgrundliggende materialer, processer m.v. Der foreslås for perifere emneområder selekteret: 3) Fagudtryk, der optræder i tekster om det prioriterede fagområde med en vis minimumsfrekvens og med en vis tekstspredning. Mens en fagordbog, hvori lemmabestanden er begrænset til egentlige fagtermer, oftest vil være tilstrækkelig til rene receptionsformål, vil en sådan rent terminologisk ordbog ikke kunne yde den fornødne hjælp i forbindelse med tekstproduktion på og oversættelse til fremmedsproget (= koncernsproget). Der er altså med henblik på tilgodeseelse af disse funktioner behov for en endnu bredere lemmaforståelse, som foruden 4) fagudtryk, der må anses for særligt vigtige eller relevante for det prioriterede delfagsområde, også bør omfatte 5) $\varnothing$ vrige leksikalske enheder, der i forbindelse med tekstproduktion på og oversættelse til fremmedsproget kan frembyde særlige grammatiske eller kollokationelle vanskeligheder.

Selektionskriterierne (2), (3), (4) og (5), der primært har til formål at sikre, at ordbogen vil kunne yde optimal hjælp i forbindelse med tekstproduktion og oversættelse, indebærer samtidig valg af makrostruktur, nemlig den alfabetiske, idet det er mere end vanskeligt at forestille sig, at udtryk selekteret i henhold til disse kriterier skulle lade sig indordne i en systematik over det prioriterede delfagsområde. Der gives en række anvisninger på, hvorledes en fagordbog, der ud over en tidsbesparende alfabetisk makrostruktur også har en i forhold til rent terminologiske produkter væsentligt udvidet lemmabestand og dermed også udvidede brugsfunktioner, samtidig kan anskueliggøre det prioriterede delfagsområdes underliggende systematiske opbygning.

Som en receptionsfremmende foranstaltning og for at introducere den ikkefagkyndige bruger til fagområdet samt etablere et overblik over faginterne sammenhænge foreslås givet en samlet systematisk fremstilling af faget. En sådan selvstændig komponent kan samtidig fungere som et samlet systematisk henvisningsgrundlag for de informationer, der optræder spredt i artiklerne i form af definitioner. Informationernes disposition og præsentation må derfor tage udgangspunkt i en systematisk ordning af stoffet, idet det først og fremmest er i denne ordbogskomponent, at den faglige systematik anskueliggøres i sin helhed. Med henblik herpå foreslås der indledningsvis udarbejdet en intern fagsystematik, forstået som en delfagsintern fagsystematik, der har til formål at etablere et overblik over det fagområde, ordbogen er planlagt til at dække. Som sådan vil den kunne udgøre grundlaget for ordbogens systematiske opbygning $\mathrm{i}$ almindelighed og en samlet systematiske fremstilling af faget i særdeleshed. Med sin karakter af skematisk overblik over fagområdet kan den interne fagsystematik fungere som en disposition for opbygningen af den 
systematiske fremstilling og dermed udgøre skelettet i denne. For at fastholde det systematiske overblik og dermed undgå, at dette fortaber sig i løbende tekst, foreslås systematikken bragt i sin helhed som introduktion til selve fremstillingen, hvis opdeling og overskrifter herefter nøje følger denne. Af hensyn til overskueligheden og for at lette brugerens tilgang til informationerne forsynes overskrifterne desuden med de i systematikken anvendte notationer. For at forebygge unødige opslag, sikre størst mulig integration af ordbogens informationer foruden hurtig tilgang til den systematiske fremstilling, indarbejdes denne eksplicit i den alfabetiske ordbog $\mathrm{i}$ form af henvisninger med notationsangivelser fra de enkelte ordbogsartiklers henvisningsfelt til det relevante sted i den systematiske fremstilling, hvor brugeren kan danne sig et overblik over fagets systematik samt hente yderligere information i en samlet kontekst.

Det nødvendige faglige overblik kan desuden fremmes gennem indarbejdelse af illustrationer. På basis af en gennemgang af praksis med tilhørende overvejelser vedr. funktion, formål m.v. anses en selvstændig illustrationsdel, der anskueligg ør del-/helhedsrelationer henholdsvis samler lemmata, der i henhold til fagets systematik har fælles nærmeste overordnede element at udgøre den mest optimale mulighed for oparbejdelse og fastholdelse af det faglige overblik vha. illustrationer. Til opfyldelse heraf foreslås der tematisk selektion af illustrationsobjekter med henblik på eksemplificering af knudepunkterne i den interne fagsystematik.

Ud over at have en monosemerende, distinktiv funktion i forbindelse med polysemi- og homonymirelationer medvirker definitioner bl.a. til at sikre den for tekstproduktion og -reception nødvendige faglige forståelse. Jeg har applikeret forskellige definitionsmetoder på det aktuelle fagsprog og fundet den semantiske feltteori mest velegnet. Som identifikationsgrundlag for et semantisk felt foreslås igen anvendt den interne fagsystematik, idet hvert enkelt knudepunkt udgør et givet felts overskrift og dermed dets overordnede element. Eksempelvis vil alle pumpetyper, der kan tilordnes feltet normalsugende flertrinspumpe med vådløber motor og halvaksial løber dels kunne defineres inden for rammerne af og i forhold til det fælles overordnede element, dels indbyrdes i forhold til de $\varnothing$ vrige elementer i feltet. Foruden felterne selv kan samtidig de feltinterne vertikale og horisontale relationer objektivt og konsekvent forhåndsfastlægges med udgangspunkt i den interne fagsystematik. Dette indebærer den yderligere fordel, at fagets systematik afspejles i definitionerne, hvorved disse bidrager til også på mikrostrukturelt niveau at støtte ordbogens underliggende systematiske opbygning.

Flerordsforbindelser udgør et særligt problem i teknisk engelsk fagsprog. Når det drejer sig om ordforbindelsers status i en fagordbog anbefales det indledningsvis at foretage en sondring mellem terminologiske og ikke-terminologiske ordforbindelser. Ud over at være definerbare som enheder, er termino- 
logiske ordforbindelser karakteriseret ved at optræde i den interne fagsystematik henholdsvis en termsystematik og vil dermed allerede være omfattet af ordbogens lemmaliste. Derudover har der i den virksomhedsinterne del af tekstkorpus kunnet identificeres adskillige eksempler på ordforbindelser, for hvilke der er tale om en yderligere udbygning af de elementer, der indgår i fagsystematikken. Specielt i forbindelse med firmaordbøger anses der at være behov for særlig leksikografisk hensyntagen til de udvidede flerordstermer, der har samtidig status af produktbetegnelser. Det videre arbejde med flerordsforbindelser har primært bestået i fastlæggelse af de leksikografiske retningslinier for identifikation og selektion af kollokationer. Mod alene at forlade sig på introspektion som empirisk basis findes der overbevisende argumenter inden for metaleksikografien. Den semantisk baserede model måtte forkastes med udgangspunkt i en række kontrolundersøgelser i autentisk tekstmateriale. Til trods for at kombinationsmulighederne ud fra en semantisk vurdering af elementernes definitoriske værdi forekom at være til stede, afslørede kontrolundersøgelser af de i autentiske tekster faktisk forekommende ordforbindelser markant kombinatorisk invarians. I stedet anbefales den tekstbaserede model dog med den væsentlige indskrænkning, at frekvenskriterier og statistiske beregninger af sandsynligheden for samtidig optræden, som ligger i naturlig forlængelse af den kontekstualistiske model, afvises som produktive kriterier for selektion af kollokationer til fagleksikografiske formål. Som empirisk basis for identifikation og selektion af kollokationer anbefales en hybridløsning, hvor introspektion, forstået som en fagkompetent vurdering af en given ordforbindelses faglige relevans, tages i anvendelse på den kontekstualistiske model. Samtidig gives en række yderligere rekommendationer, f.eks. vedr. bortkastning af ordforbindelser, hvori der ikke består en grammatisk relation mellem elementerne indbyrdes, foruden en metode til vurdering af en ordforbindelses potentielle sprogproduktionsmæssige relevans på baggrund af en række grammatiske, semantiske og leksikalske overvejelser, der tager udgangspunkt i ordbogens brugsfunktioner og den intenderede målgruppes forudsætningsniveau.

På baggrund af en detaljeret diskussion af forskellige problemtyper konstateret med udgangspunkt $i$ tekstkorpus og relateret til den almensproglige grammatik, således som den fremstilles i den største eksisterende engelske grammatik, A Comprehensive Grammar of the English Language, gives en række brugerbehovs- og brugsfunktionsrelaterede rekommendationer vedr. indarbejdelse af grammatiske oplysninger, herunder disses detaljeringsgrad og fordelingsstruktur. Denne diskussion skal samtidig ses som et væsentligt forarbejde til en differensgrammatik for det pågældende fagsprog, dvs. en selvstændig, empirisk baseret grammatik, der beskriver konstaterede karakteristika og afvigelser i forhold til den almensproglige grammatik. 


\section{Koncept}

Afhandlingen afsluttes med et koncept til en brancheordbog bestående af en monolingval engelsk basisordbog med tilhørende dansk-engelsk lemmaliste.

\section{Litteratur}

\section{Ordbøger}

Dansk-engelsk teknisk ordbog. (1990) København: Grafisk Forlag.

Engelsk-dansk teknisk ordbog. (1991) København: Grafisk Forlag.

Langkilde, Charlotte et al. (1990) : L \& H Teknisk Ordbog dansk-engelsk lengelskdansk. L \& H Ordbøger.

\section{Sekundær litteratur}

Bergenholtz, Henning \& Pedersen, Jette (1994): Grammar in bilingual LSP dictionaries, with a special view to technical English. In: Burkhard Schaeder/Henning Bergenholtz (Hrsg): Das Fachwörterbuch. Fachwissen und seine Repräsentation in Wörterbüchern. Tübingen: Narr 351-383.

Bergenholtz, Henning \& Pedersen, Jette (1994): Zusammensetzung von Textkorpora für die Fachlexikographie. In: Burkhard Schaeder/Henning Bergenholtz (Hrsg): Das Fachwörterbuch. Fachwissen und seine Repräsentation in Wörterbüchern. Tübingen: Narr, 161-176.

Bergenholtz, Henning; Pedersen, Jette og Tarp, Sven (1994): Basic Issues in LSP Lexicography. In; H.Bergenholtz/A.Lykke Jakobsen/B.Maegaard/H.Mørk/P.SkyumNielsen: Translating LSP Texts. OFT Symposium. Handelshøjskolen i København 11-12 april 1994. København, 151-187.

Bergenholtz, Henning/Pedersen, Jette: Fachwörterbücher als Hilfsmittel bei der Übersetzung von Fachtexten. In: Lothar Hoffmann, Hartwig Kalverkämper, Herbert Ernst Wiegand (Hrsg): Fachsprachen: Ein internationales Handbuch zur Fachsprachen-forschung und Terminologiewissenschaft. Berlin: de Gruyter (i trykken).

Pedersen, Jette (1995): Systematic classification. In: H.Bergenholtz/S.Tarp (eds): Manual of Specialised Lexicography. Amsterdam: John Benjamins Publishing Co., 83-90.

Pedersen, Jette (1994): Equivalent selection. In: H.Bergenholtz/S.Tarp (eds): Manual of Specialised Lexicography. Amsterdam: John Benjamins Publishing Co., 104-110.

Pedersen; Jette (1994): Anskueliggørelse af faglige relationer i brancheordbøger. In: LexicoNordica 1, 203-228.

Pedersen; Jette (1995): Grammatiske oplysninger i tekniske fagordbøger. In: LexicoNordica 2, 121-142.

Pedersen, Jette (1995): Koncernspecifik brancheordbog med sarligt henblik på teknisk engelsk. Preekonceptionelle overvejelser og koncept. Handelshøjskolen i Århus (upubliceret Ph.D. afhandling). 
Pedersen, Jette (1995): The Identification and Selection of Collocations in Technical Dictionaries. In: Jahrbuch Lexicographica 11 (i trykken).

Quirk, Randolph; Greenbaum, Sidney; Leech, Geoffrey/Svartvik, Jan (1991): A Comprehensive Grammar of the English Language. London and New York: Longman. 